\title{
Diagnosis of Krabbe's infantile leucodystrophy
}

\author{
BENGT HAGBERG, PATRICK SOURANDER, AND \\ LARS SVENNER HOLM
}

\author{
From the Paediatric Clinic, University of Uppsala, Uppsala, and the Departments of Pathology \\ and Medical Biochemistry, University of Gothenburg, Gothenburg, Sweden
}

Increasing interest is now being paid to a correct diagnosis in the early stages of the different types of degenerative diseases of the central nervous system of infancy and childhood. Among the diseases which affect the white matter of the nervous system a subgroup is recognized as the heredo-degenerative type or the leucodystrophies. In 1956 Poser and van Bogaert (1956) stated that it was almost imposslble to make a clinical diagnosis of the leucodystrophies unless there was a well-documented family history. However, by the demonstration of a characteristic sulphatide pattern of urinary sediment lipids by paper chromatography the metachromatic type of leucodystrophy (sulphatidosis) can now be diagnosed during life (Hagberg and Svennerholm, 1960; Hagberg, Sourander, and Svennerholm 1961). It can also be diagnosed through the demonstration of brown metachromatic granular deposits in peripheral nerve biopsy specimens (Thieffry and Lyon, 1959; Hagberg, Sourander, and Thorén, 1962). In the other important type of leucodystrophy, the globoid cell type of Krabbe's disease, no characteristic clinical laboratory tests have hitherto been described. However, diagnostic help can be obtained from analysis of the proteins of the cerebrospinal fluid. This will be shown in six well-documented cases of Krabbe's disease.

\section{CASE HISTORIES}

CASE 1 E.M., born in 1959, was the second girl of two. Her elder sister had died aged 10 months of a disorder with a nearly identical clinical picture. The patient developed normally during her first few months of life. However, she was restless and cried more than usual from 7 weeks of age. From about 4 months of age she showed irritability, and regression of mental and motor development and general stiffness. One month later she lay in the opisthotonus position with extended and crossed legs, and variable muscular hypertonus, bilateral ankle clonus, and degenerative changes of the visual fields were seen. When 6 months old she was blind with optic atrophy, had no contact with her surroundings, was hyperaesthetic and cried violently, had clonic fits, and was in a state of extensor rigidity. The serum lipids were: cholesterol $126 \mathrm{mg} . / 100 \mathrm{ml}$., phospholipids 169 mg./100 ml., triglycerides $79 \mathrm{mg} . / 100 \mathrm{ml}$. She died aged $20 \frac{1}{2}$ months old.

CASE 2 A.W., a girl born in 1960, was the first child of a healthy family and appeared normal until 1 month old. She then started to be irritable and screamed frequently. Regression of mental and motor development, general stiffness, and fever of unknown origin, were noted about two months later. When 5 months old she was severely retarded, lay in the opisthotonus position with extended and crossed legs, and showed muscular hypertonus of variable intensity. The serum lipids on two different occasions were: cholesterol 118, $141 \mathrm{mg} . / 100 \mathrm{ml}$; phospholipids $162,167 \mathrm{mg}$. $/ 100 \mathrm{ml}$; ; lecithin $129,133 \mathrm{mg}$./ $100 \mathrm{ml}$; sphingomyelin $37,38 \mathrm{mg} . / 100 \mathrm{ml}$. triglycerides $83,68 \mathrm{mg} . / 100 \mathrm{ml}$. Cholecystography was normal. She died aged $7 \frac{1}{2}$ months.

CASE 3 K.J., a girl born in 1961, was the third child of a family where an elder brother had died at the age of 13 months with the same clinical picture. This girl was healthy and normal until $4 \frac{1}{2}$ months old, when she started to cry day and night. When she cried, clonic fits were observed in the arms and legs. She rapidly regressed in development and soon showed a state of variable hypertonicity. She also had bouts of fever without any signs of infection. When 6 months old she was markedly hyperaesthetic and lay in a constant opisthotonus position, with extensor rigidity. She was probably blind and was hypersensitive to sounds. The serum lipids were: cholesterol $202 \mathrm{mg}$./100 ml., phospholipids $222 \mathrm{mg}$./100 ml., lecithin $161 \mathrm{mg} / 100 \mathrm{ml}$., sphingomyelin $56 \mathrm{mg} . / 100$ mg., triglycerides $71 \mathrm{mg} . / 100 \mathrm{ml}$. Cholecystography was normal. She died aged $16 \frac{1}{2}$ months.

CASE 4 E.S., a girl born in 1958, was the eldest sister of three, case 5 being the youngest one. Her mental and motor development was quite normal until 4 months of age when she stagnated and then lost already acquired mental and motor skills. When 6 months old she was found to be irritable, unable to sit or grasp, the muscles hypotonic, and mentally backward. In addition she had oscillating eye movements and an increased concentration of cerebrospinal fluid proteins (Bisgaard $1: 60$ ). One month later she was found to be in a poor condition, lay in the opisthotonus position, and showed marked extensor rigidity. When 13 months old she was in a state 
of decerebrate rigidity, suspected to be blind, and had generalized convulsions and also minor clonic fits. She died aged 15 months.

CASE 5 M.S., born in 1960, was the youngest sister of case 4. One elder sister born in 1959 is healthy. The patient was found to have bilateral talipes at birth but otherwise was healthy and developed normally until 4 months old. From this time on a rapid general regression was noted and a state of extensor rigidity developed within a few months. Bouts of a non-infectious type of fever, episodes of sweating, and fits of tonic or clonic type were frequently observed. The serum lipids were on two different occasions: cholesterol 188, $215 \mathrm{mg} . / 100 \mathrm{ml}$.; phospholipids $255,251 \mathrm{mg} . / 100 \mathrm{ml}$; triglycerides 195 , $126 \mathrm{mg} . / 100 \mathrm{ml}$. Since the age of about 1 year she is in a 'burnt-out state', probably blind, with minimal spontaneous movements, nystagmus, optic atrophy, and bulbar signs. She was still alive in June 1962, aged 2 years.

CASE 6 R.T., a boy born in 1959, was the only child of a healthy family. He was born in a normal delivery but vomited from the first week of his life. According to his mother nothing else abnormal was observed in his general development during his first few months. When $2 \frac{1}{2}$ months old he was taken to the local paediatric department on account of vomiting and malnutrition. At the hospital unusual bouts of screaming, slightly hyperkinetic movements, and pathological variations in muscular tone were seen after about one week of observation. When 4 months old he developed a more constant type of extensor rigidity and usually lay in the opisthotonus position. He was now also found to be hypersensitive to touch. From about the same time mental retardation was noted. He died when $14 \frac{1}{2}$ months old.

\section{LABORATORY DIAGNOSIS}

The determination of total protein content and paper electrophoresis of cerebrospinal fluid were performed in cases $1,2,3$, and 5 with essentially the same methods as used by Widdell (1958). In case 4 the determinations were carried out in another laboratory with the methods of Wallenius (1952). In case 6 no electrophoretic analysis was performed.

The results are given in Table I. For comparison the figures found by Widdell (1958) in normal infants of 5 to 8 months of age are also reported.

Sulphatides of urinary casts were examined in cases 1 to 5 with the same technique as applied to urine from cases with metachromatic leucodystrophy (Hagberg and Svennerholm, 1960). The excretion of sulphatides were regularly found to be low.

\section{POST-MORTEM EXAMINATION}

Pathology The diagnosis was verified by necropsy in cases $1,2,3,4$, and 6 . In cases 1 and 2 detailed histological and histochemical studies were carried out on the nervous system, endocrine, and visceral organs. The presence of numerous epitheloid or globoid cells already described by Beneke (1908), Krabbe (1916), and Collier and Greenfield (1924) in the extensively demyelinated white matter of the brain was the most remarkable and pathognomonic feature. Most of the globoid cells occurred in clusters around capillaries and venules. Their nuclei were often multiple and their cytoplasm was either homos genous or finely granular. In frozen sections treated with cresyl violet-acetic acid according to the method of von Hirsch and Peiffer (1955) no cytoplasmie metachromasia was observed. The globoid cells stained dull pink with Scarlet R. The periodic-acid $\stackrel{0}{-}$ Schiff reaction according to McManus (Pearse, 1960) revealed a red colour of varying intensity which was still visible after extraction with chloroformmethanol $(2: 1, \mathrm{v} / \mathrm{v})$ at $60^{\circ} \mathrm{C}$., thus indicating the presence of non-lipid carbohydrates. There were no signs of lipid storage in the reticulo-endothelial cells of liver, spleen, lymph nodes, and bone marrow.

TABLE I

CONCENTRATION OF TOTAL PROTEINS AND THEIR DISTRIBUTION IN CEREBRCSPINAL FLUID

\begin{tabular}{|c|c|c|c|c|c|c|c|c|}
\hline Case No. & 1 & 2 & 3 & $4^{1}$ & & 5 & 6 & $\begin{array}{l}\text { Normal Infants } \\
\text { (Widdell, 1958) }\end{array}$ \\
\hline $\begin{array}{l}\text { Age at examination }(\mathrm{mth} .) \\
\text { Total proteins }(\mathrm{mg} . / 100 \mathrm{ml} .)\end{array}$ & 192 & $\begin{array}{r}5 \\
156\end{array}$ & $\begin{array}{r}5 \\
173\end{array}$ & $\begin{array}{l}15 \\
85\end{array}$ & $\begin{array}{r}8 \\
103\end{array}$ & $\begin{array}{l}24 \\
92\end{array}$ & $\begin{array}{r}4 \\
166\end{array}$ & $\begin{array}{l}5-8 \\
15 \cdot 6-25 \cdot 2\end{array}$ \\
\hline $\begin{array}{l}\text { Relative percentage distribution } \\
\text { Pre-albumins } \\
\text { Albumins } \\
a_{1} \text {-globulins } \\
a_{2}-\text { globulins } \\
\beta \text {-globulins } \\
\gamma \text {-globulins }\end{array}$ & $\begin{array}{r}0 \cdot 5 \\
75 \cdot 7 \\
4 \cdot 3 \\
5 \cdot 1 \\
9 \cdot 6 \\
4 \cdot 8\end{array}$ & $\begin{array}{r}1 \cdot 4 \\
73 \cdot 3 \\
4 \cdot 9 \\
5 \cdot 6 \\
10 \cdot 1 \\
4 \cdot 7\end{array}$ & $\begin{array}{r}0 \cdot 5 \\
74 \cdot 8 \\
4 \cdot 6 \\
5 \cdot 7 \\
10 \cdot 9 \\
3 \cdot 5\end{array}$ & & \begin{tabular}{r|}
$3 \cdot 0$ \\
$77 \cdot 7$ \\
$3 \cdot 7$ \\
$4 \cdot 6$ \\
$8 \cdot 2$ \\
$3 \cdot 8$
\end{tabular} & $\begin{array}{r}1 \cdot 2 \\
72.9 \\
4 \cdot 8 \\
6.9 \\
9 \cdot 2 \\
5 \cdot 0\end{array}$ & & $\begin{array}{c}2 \cdot 5-4 \cdot 9 \\
56 \cdot 1-70 \cdot 9 \\
2 \cdot 0-5 \cdot 2 \\
3 \cdot 7-7 \cdot 5 \\
14 \cdot 8-20 \cdot 0 \\
3 \cdot 6-8 \cdot 8\end{array}$ \\
\hline
\end{tabular}

In case 4 a different electrophoretic method was used. The figures obtained cannot, therefore, be directly compared with those for cases 1,2 , 3 , and 5 , but case 4 also presented a relative increase of albumins and low figures for all globulins.

${ }^{2}$ The figures are calculated from the mean values \pm 2 S.D. 
No multinucleated typical globoid cells were seen in organs other than the brain. No macroscopic or microscopic changes were seen in the gall bladder or kidney. The pituitary, thyroid, adrenals, ovaries, and insular cells of the pancreas were all normal.

CHEMISTRY Unfixed tissue taken soon after the patients died in cases 1,2 , and 4 and formalin-fixed material from case 6 were investigated using the methods earlier applied in cases with metachromatic leucodystrophy (Hagberg, Sourander, Svennerholm, and Voss, 1960).

The lipid composition of the cerebral grey matter was relatively normal except for a low concentration of sulphatides. Obvious changes were seen only in the cerebral white matter (Table II) in which the concentration of lipids was lower than in the cerebral cortex.

Since it has been assumed that the physiological maturation of myelin is inhibited in Krabbe's disease, the lipid content of the cerebral white matter in the present cases is compared with that of the white matter of two 1-month-old infants. In Krabbe's disease there are lower concentrations of cholesterol and glycerophospholipids than in normal infants but the concentrations of sphingomyelins, and especially cerebrosides, are higher. Only a small part of the cerebrosides occur as sulphuric acid esters (sulphatides) in all the cases. The sphingomyelins, cerebrosides, and sulphatides have been isolated and classified. They have the same composition and physico-chemical properties as corresponding lipids from normal brains. In material from the spinal cord the deviations from the normal lipid pattern are smaller while in peripheral nerves there is no significant difference from the normal lipid composition. It means that the lipid composition is only seriously disturbed where the proteolipids constitute a predominant part of the myelin structure.

\section{DIAGNOSTIC COMMENTS}

The history and neurological signs in typical cases should early suggest the diagnosis; pathognomonic signs, however, are lacking. Usually the infants develop normally until 3 to 5 months of age, when first stagnation and later deterioration of mental and motor performances occur within a few weeks. At the same time, or even earlier, may be observed irritability, frequent episodes of crying, slight stiffness in the limbs, and hypersensitiveness when the baby is touched and handled. The full-blown neurological picture, which is reached in a short time, is characterized by the opisthotonus posture with extended and crossed legs, marked generalized hypertonus of variable intensity, minor tonic or clonic fits in the extremities induced by all sorts of stimuli, and optic atrophy. In addition periods or episodes of high fever without any signs of simultaneous infection are characteristic. The active stages of the disease are usually passed in a few months. Before the patients die most of them enter a final, inactive, and often long-lasting period characterized by severe mental retardation, decerebrate rigidity, blindness, and emaciation.

The cerebrospinal fluid presents a normal cell count but shows an increase of the proteins with a relative distribution of the protein fractions as in the early stages of the Guillain-Barre syndrome. There is an increase in the albumin and the $\alpha_{2}$-globulin fractions, the latter being distinctly demarcated, and a reduction of $\beta_{1}$-globulin and the $\gamma$-fractions. In contrast, however, to the subsequent changes in the Guillain-Barré syndrome the same electrophoretic pattern remains constant throughout the disease in cases of Krabbe's disease. Except in cases of metachromatic leucodystrophy (Hagberg and Svennerholm, 1960) we have not seen this electrophoretic pattern in other demyelinating processes.

\section{TABLE II}

LIPID COMPOSITION OF CEREBRAL WHITE MATTER (FRONTAL LOBE) IN CASES WITH KRABBE'S DISEASE AND IN TWO 1-MONTH-OLD NORMAL INFANTS

\begin{tabular}{|c|c|c|c|c|c|}
\hline Case No. & 1 & 2 & 5 & 6 & Normal Infants \\
\hline Age at death (mth.) & $20 \frac{1}{2}$ & $7 \frac{1}{2}$ & 15 & $14 \frac{1}{2}$ & 1 \\
\hline Water & $85 \cdot 5$ & 86.0 & $83 \cdot 8$ & - & $89 \cdot 1$ \\
\hline Total nitrogen & $12 \cdot 30$ & $10 \cdot 75$ & $11 \cdot 49$ & 11.04 & $8 \cdot 73$ \\
\hline Total hexosamine & 0.69 & 0.67 & 0.67 & 0.68 & 0.83 \\
\hline Total lipids & $21 \cdot 8$ & $24 \cdot 4$ & $18 \cdot 1$ & $23 \cdot 5$ & $30 \cdot 6$ \\
\hline Cholesterol & $4 \cdot 3$ & $5 \cdot 0$ & 2.9 & 5.8 & $8 \cdot 0$ \\
\hline Phospholipids & $15 \cdot 6$ & $16 \cdot 0$ & $13 \cdot 1$ & $14 \cdot 0$ & $21 \cdot 0$ \\
\hline Kephalins & $7 \cdot 6$ & $6 \cdot 5$ & $5 \cdot 6$ & $5 \cdot 0$ & $9 \cdot 5$ \\
\hline Lecithins & $6 \cdot 1$ & 6.9 & $5 \cdot 1$ & $6 \cdot 3$ & $9 \cdot 6$ \\
\hline Sphingomyelins & $2 \cdot 1$ & $2 \cdot 1$ & $2 \cdot 4$ & $2 \cdot 6$ & $1 \cdot 2$ \\
\hline Homoglycolipid-hexose & $0 \cdot 39$ & $0 \cdot 72$ & 0.45 & 0.80 & $0 \cdot 35$ \\
\hline Cerebrosides & $1 \cdot 7$ & $2 \cdot 5$ & $2 \cdot 0$ & $3 \cdot 0$ & \\
\hline Sulphatides & $0 \cdot 16$ & 0.9 & $0 \cdot 12$ & 0.7 & \\
\hline Lipid-hexosamine & 0.083 & 0.090 & - & $0 \cdot 143$ & 0.153 \\
\hline
\end{tabular}

All values except water expressed as percentage of dry weight. 
In our cases of Krabbe's disease the urinary sulphatides were of low concentration and of normal type, while in late infantile metachromatic leucodystrophy they were found in increased concentrations with a specific chromatographic pattern. The estimation of sulphatides in urinary sediment can therefore be used to differentiate between these two forms of leucodystrophy.

Peripheral nerve biopsy specimens were normal in all the four cases of Krabbe's disease examined (cases 1 to 4), while they show pathognomonic changes in metachromatic leucodystrophy.

Histological and chemical studies of brain biopsy specimens were used as a diagnostic method by Blackwood and Cumings (1954). The demonstration of the characteristic globoid cells, which are present in large numbers in the demyelinated cerebral white matter, has pathognomonic diagnostic significance.

Other organs were examined histologically to find whether globoid cells occurred outside the nervous system in organs which could be used for diagnostic biopsy examination. We were unable to find any globoid cells in the visceral organs, lymph nodes, or bone marrow. Multinucleated giant cells of the foreign body type were present in the lungs of two of our cases which had bronchopneumonia. These cells did not have the typical structure of the globoid cells. This is in contrast to the findings of Hager and Oehlert (1957) who demonstrated, in one case, giant cells not only in the lungs but also in the spleen and the mesenteric lymph nodes.

Thus, except for the examination of brain biopsy specimens, the most valuable diagnostic information during life is obtained from the characteristic history, neurological signs, and increased cerebrospinal fluid proteins with a typical electrophoretic pattern.

A definite diagnosis of Krabbe's disease can only be established by the demonstration of globoid cells in a diffusely demyelinated white matter of the brain in biopsy specimens or at post-mortem examination. Chemical analyses of the brain demonstrate a lipidpoor cerebral white matter with low concentrations of all tissue lipids, which have not yet been seen in any other brain disorder.

\section{SUMMARY}

The clinical history and neurological signs in six typical cases of Krabbe's infantile leucodystrophy are described. The diagnosis was established in five cases at necropsy. The sixth case is a younger sister of one of the other cases.

The total protein content of the cerebrospinal fluid samples was increased three- to ten-fold. A significant relative increase of albumins and a decrease of $\beta$-globulins was shown by paper electrophoresis. The diagnostic value of the clinical history, neurological signs, and cerebrospinal fluid analyses is discussed.

We are indebted to Dr. William Mair, National Hospital, Queen Square, London, for helpful advice on the preparation of the manuscript, and to Sister Ruth Andersson, Neurological Clinic, Sahlgren's Hospital, Gothenburg, for the cerebrospinal fluid analyses. We studied case 1 in collaboration with Dr. Brandberg, case 2 with Dr. Hermansson, case 3 with Drs. Söderling and Bergström, case 4 with Dr. Söderhjelm, case 5 with Drs. Palmgren and Söderhjelm, and case 6 with Drs. Kostman and Pehrsson. Financial support was given by Expressens Prenatalforskningsnämnd, Scoutfonden für blind ocl synsvag ungdom, and Transatlantic Shipping Co.

\section{REFERENCES}

Beneke, R. (1908). Arch. Kinderheilk., 47, 420.

Blackwood, W., and Cumings, J. H. (1954). J. Neurol. Psychiat., 1 33.

Collier, J., and Greenfield. J. G. (1924). Brain, 47, 489.

Hagberg, B., Sourander, P., and Svennerholm, L. (1961). Cerebr. Palsy Bull., 3, 438.

,,,--- and Voss, H. (1960). Acta paediat., (Uppsala), 49, 135.

and Thorén, L. (1962). Ibid., 51, suppl., 135, p. 63. and Svennerholm, L. (1960). Ibid., 49, 690.

Hager, H. and Oehlert, W. (1957). Z. Kinderheilk., 80, 82.

Hirsh, T. von, and Peiffer, J. (1955). Arch. Psychiat. Nervenkrank., $194,88$.

Krabbe, K. (1916). Brain, 39, 74.

Pearse, A. G. E. (1960). Histochemistry, 2nd ed., p. 832. Churchill, London.

Poser, C. M., and van Bogaert, L. (1956). Acta psychiat. scand., 31, 285.

Thieffry, S., and Lyon, G. (1959). Rev. neurol., 100, 452.

Wallenius, G. (1952). Acta Soc. Med. upsalien., 57, 138.

Widdell, S. (1958). Acta paediat. (Uppsala), 47, suppl., 115. 